\title{
Relationships between Accounting Information on the Business Financial Statements and the Stock Price: A Study with LASSO Method
}

\author{
Hoang Thi Viet HA ${ }^{1}$, Dang Ngoc HUNG ${ }^{2}$, Ngo Thanh XUAN ${ }^{3}$ \\ ${ }^{1} \mathrm{Ph}$. Dr Hanoi University of Industry, Vietnam; E-mail: hoangthivietha@gmail.com \\ 2Professor, Ph.Dr, Hanoi University of Industry, Vietnam; E-mail: dangngochung@haui.edu.vn; \\ hungdangngockt@yahoo.com.vn \\ ${ }^{3}$ The National Economics University, Vietnam; E-mail: xuantn@neu.edu.vn \\ * Corresponding Author
}

$\begin{array}{llll}\text { Received: 04.11.2021 } & \text { Accepted: 14.12.2021 } & \text { Published: 01.02.2022 } & \text { DOI: 10.47750/QAS/23.186.31 }\end{array}$

\begin{abstract}
This article examines the relationship between financial statement accounting information and stock prices of companies listed on the Vietnamese stock market. This study conducts a thorough examination of accounting information contained in the company's financial statements and uses the LASSO approach to identify factors affecting stock prices. Between 2008 and 2019, data for 52 indicators were gathered. According to research findings, several characteristics, including book value, firm size, profitability, and rapid solvency ratio, are statistically significant and positively correlate with stock price. The authors present several recommendations for investors, corporations, and policymakers based on their research findings.
\end{abstract}

Keywords: Accounting information; Stock price; LASSO method

\section{Introduction}

Transparency and trustworthiness of financial information are the theoretical and practical foundations that are critical for investor protection and stock market stability. When it comes to investing in the stock market, it is critical and desirable for investors to have access to important financial information. Investors rely on their examination of accounting information contained in financial statements to determine the efficiency of a corporation. As a result, investors ultimately decide whether to buy or sell a company's shares. Stock prices are influenced by a variety of factors, including the financial statements' accounting information. Numerous researches on the relationship between stock prices and accounting information have been conducted in industrialized countries (net profit, earnings per share, book value per share, etc.) Ball \& Brown (1968) undertook an empirical examination of the relationship between accounting information and New York Stock Exchange stock prices (NYSE). Their findings indicate that the profit reported in financial statements has an effect on stock prices, and they argue that corporate earnings are useful in determining stock prices. Additionally, Lev \& Ohlson (1982) and Walker (1997) conducted experimental studies to examine the relationship between publicly available accounting information and stock prices.

Ohlson's (1995) study model extends previous research on the relationship between accounting information and stock prices by include balance sheet ratios as measured by net assets and other financial parameters. The findings of Ohlson's research have significantly affected and reaffirmed the conclusion that accounting information has an effect on stock prices. As a result, several empirical studies have been done to determine the worth of pertinent financial statement information in various markets. Collins et al. (1997) examined stock price movements in the United States over a 40-year period in relation to profit and equity book value. They developed a regression model using the net profit models as a theoretical foundation to determine the relationship between stock value, book value of equity, and returns. Simultaneously, it demonstrated that financial report information, as described by the Ohlson model, accounts for $54 \%$ of the US stock market's value. King \& Langli (1998) utilized a regression model to examine earnings and book value per share, and their findings indicated that the UK, Norway, and Germany all had explanatory capacities of $70 \%, 60 \%$, and $40 \%$, respectively. This finding demonstrates considerable changes in the link between accounting information and stock prices between nations and throughout time.

According to the FASB, the financial statements' goal is to give information about a company's financial situation, performance, and changes in financial position in order to assist various stakeholders in making financial decisions. Financial statements contribute to the provision of meaningful information for loan investment decisions by evaluating the time and uncertainty of cash flows and by disclosing information about economic resources, property rights, and modification. The impact of accounting information on financial statements on stock prices has long attracted scholars' attention, particularly in emerging stock markets such as Vietnam. This study evaluates and enhances earlier research on accounting information on financial statements (52 indicators), including information on the company's size, financial structure, solvency, and asset utilization efficiency, to determine their effect on the 
stock price. Additionally, this study employs the LASSO approach, which is similar to the OLS method, to estimate the parameters of the regression model by minimizing the objective function, which is the sum of squares of the residuals. However, LASSO imposes the limitation that the total absolute value of the parameters does not exceed that of a single tuning parameter. The LASSO approach will be implemented in detail in Section 4. Research Methodology.

\section{Theoretical Basis}

\subsection{Representative theory}

The representative hypothesis is drawn from Jensen \& Meckling's economic theory (1976). This theoretical topic is concerned with the contractual relationship between the principal and the authorized party. Proxy relationships are most prevalent between shareholders and corporate executives, as well as between creditors and corporate shareholders. Contrary to the proxy's expectation of maximization of advantages, the representatives, who are frequently the company's executives, occasionally have their own agendas. They accomplish this by making modifications to the financial statements. Financial statements no longer accurately reflect the financial condition, business operations, and cash flow of the organization. As a result, it provides no helpful information to investors, shareholders, or creditors. Additionally, Jensen \& Meckling (1976) suggested that auditing operations could help management and external shareholders avoid conflict. Auditors act as shareholders' supervisors because they identify discrepancies in audited financial accounts. The research employs this idea in the hope that audited accounting data will adequately explain the volatility of listed firms' stock prices. The audited financial statement data is more pertinent to the inquiry.

\subsection{Signaling theory}

Spence (1973) proposed this idea to explain the labor market's knowledge asymmetry. His idea implies that if parties communicate with one another, asymmetric information problems can be avoided. Additionally, it has been used to clarify disclosures in corporate reports (Ross, 1977). According to signaling theory, regulators are anticipating a signal, and financial statement information is one of the signaling mediums. Companies produce financial statements to demonstrate to traders that they are superior to other companies in the market, with the goal of attracting investment and enhancing their reputation. The signaling theory describes the behavior of two parties: those who hold knowledge and those who signal to the market and use that information. This theory seeks to alleviate the asymmetry of knowledge between the informed and the impoverished. Companies use financial statement data to communicate with the market. A well-prepared financial statement is a reputable source of information, instilling confidence in investors and associated entities by demonstrating that the revealed information is transparent and reliable. Companies can enhance the quality of their financial statements by implementing internal control activities and training accounting employees, as well as adhering to tax and accounting requirements. Thus, the signaling hypothesis helps to explain why investors react appropriately to accounting information received from businesses.

\subsection{The efficient market theory}

A market that is efficient is one in which investors can obtain the same information at any moment and promptly act in the same homogeneous manner, such that all information is reflected in the securities market price. Because stock prices are unpredictable in efficient markets, stock returns will likewise be random and largely conform to the normal distribution. The market is classified into three efficiency levels: (i) low form efficiency, (ii) semi-high form efficiency, and (iii) high form efficiency. The weak form efficiency presupposes that the current price is an accurate representation of historical prices. At the semi-strong form efficiency level, the stock price accurately reflects all publicly available information and corporate information, such as profit, dividends, and management announcements. It is hard to implement trade regulations based on internal knowledge with high form efficiency because market prices already reflect such information (Malkiel \& Fama, 1970).

If the accounting information released has an effect on the share price, the market is now classed as semi-strong form efficient. According to Ohlson (1995), stock values are integrated from two accounting variables: book value per share and earnings per share.

Thus, the Reference Information Model (RIM) model divides the intrinsic value of a security into two components: the book value and the value derived from the security's present value as determined by the stock's future residual profits. This pricing model permits the investigation of how a business creates value for its owners. If the return on equity exceeds the cost of equity, the intrinsic value of the stock exceeds its book value, and the corporation is perceived to be creating shareholder value. If the cost of equity exceeds the rate of return on equity, the corporation risks destroying its equity value. Discounting residual earnings is a straightforward calculating procedure that is reasonably simple to understand. This strategy, however, is applicable only to corporations with solid future dividend policies. The justification for this strategy is that it should discount future income flows (including dividends and predicted selling prices) to the present and then compare the estimated price to the stock market price. If the estimated price is greater than the market price, investors should purchase; conversely, if the estimated price is less than the market price, investors should sell. As a result, if this strategy is applied to bonds, it will be more acceptable, as the future income streams supplied by bonds are typically steady and predictable, as opposed to stocks' volatility. Ohlson (1995) released his valuation model after describing the theory underlying the stock price model based on the residual return stream. This approach is regarded as one of the most significant advances in capital market research in the 1990s and serves as the foundation for defining research objectives and values. The Ohlson model properly addressed two problems posed by Ball \& Brown (1968), the inventors of stock valuation, about the financial statement information to include when constructing a value measurement model (Dung, 2010). Thus, by combining the residual profit model with Ohlson's (1995) information series, Ohlson developed a model that illustrates the relationship between stock price and two direct financial statement items, profit and book value per share.

Aboody et al. (2002) published "Measuring value relevance in a (possibly) inefficient market." The authors defined an ineffective market as one in which the price of securities (especially stocks) does not accurately represent their actual value. This implies that stock prices do not reflect all relevant market information or that the semi-strong form efficiency hypothesis is violated. There may be a correlation between the financial statements' information and the aforementioned inaccuracy. Because stock prices are a function of the accumulation of company-related knowledge, any market weakness can be compounded by additional details to produce perplexing results. However, these effects, in our judgment, will diminish over time and will be reflected in the security's future 
returns.

\section{Literature Reviews}

The research cited above demonstrate that equity information has a beneficial effect on stock price and profit information. They explore the relationship between accounting information and stock prices using Ohlson's (1995) model as the underlying theoretical framework. Barth et al. (1998) investigated the book value of stock and its profit margin in relation to the financial capability of the company. They calculated a company's financial capacity using bonds and two data samples from the United States. For the period 1993-2009 in India, Sharma et al. (2012) evaluated the empirical link between stock prices and explanatory accounting variables such as book value per share, dividend per share, earnings per share, dividend yield, and dividend. Their findings indicated that earnings per share, dividend per share, and book value per share all had a significant impact on the market price of a stock. Stark \& Thomas (1998), Lo \& Lys (2000), and Akbar \& Stark (2003) all demonstrated that stock price is favorably correlated with book value and earnings. The interpretability of the model when both book value and income are included is nearly identical to that of the model when just book value is included. As a result, the dividend, in addition to earnings and book value of equity, has an effect on the stock price. This finding corroborates the findings of prior research conducted by Stark \& Thomas (1996), Rees (1997), and Alfaraih \& Alanezi (2011).

Collins et al. (1997) examined the impact of earnings and book value information on the stock prices of publicly traded companies in the United States from 1953 to 1993. The study demonstrates that the model's overall explanatory level is $54 \%$ and does not decrease over time. However, explainability of returns tends to decline over time, whereas book value increases.

Chen et al. (2001) examined equities in the Chinese stock market from 1991 to 1998 using the Ohlson model (1995). The authors demonstrated that profit and book value are variables that correlate positively with stock price movements. Additionally, the findings of this study indicate that firms with a higher frequency of losses will have a stronger negative correlation between earnings and stock prices (a finding that corroborates Collins et al., 1997); the relationship between accounting information and stock prices is stronger for small firms, and accounting information contributes more to explaining stock price movements for high liquid stocks.

Numerous empirical investigations in developing nations have been conducted using Ohlson's (1995) model, including Shamki (2012) in Jordan, Khanagha (2011) in the United Arab Emirates, Omokhudu \& Ibadin (2015) in Nigeria, and Khanna (2014) in India. The preceding research established a correlation between accounting data on a company's financial statement and stock prices with varying degrees of explanation. Along with research focused on book value and earnings per share, a variety of studies link stock prices to other financial statement variables. According to lqbal et al. (2014), ROA has a favorable effect on stock prices. Apart from that, financial leverage refers to the extent to which a business utilizes fixedincome securities such as debt and equity. The more debt a business incurs, the greater its financial leverage. Financial leverage results in excessive interest payments, which have a detrimental impact on a company's earnings per share. According to Kaundal \& Sharma (2010), financial leverage has the reverse effect on stock values. This implies that increased financial leverage will result in lower stock values and vice versa. Collins \& Kothari (1989) and Sharma et al. (2012) found that firm size and growth rate have a beneficial effect on stock prices. King \& Langli (1998) used the Ohlson (1995) model to analyze the effect of accounting information on stock prices in three nations with disparate accounting systems, namely the United Kingdom, Germany, and Norway, between 1982 and 1996. According to the research findings, the amount of explanation for price fluctuations in shares in these three stock markets is $70 \%, 40 \%$, and $60 \%$, respectively. Additionally, profits and book value are understood differently over time and among countries. Book value, in instance, has a bigger impact on the price movements of companies listed on the German and Norwegian stock exchanges than profit, but profit has a greater impact on the UK stock market than book value.

\section{Research Methodology}

\section{Research models}

As a result of the preceding literature analysis, the following concerns arise: Is Ohlson's (1995) model relevant for Vietnam's stock market? Does the model adequately explain the relationship between accounting information and stock prices? Using this model, this study evaluates the effect of accounting information on the stock prices of enterprises listed on the Vietnamese stock market. The study used a linear regression model with the share price as the dependent variable and 52 indicators of financial statement accounting information as the independent variables. We propose an updated model combining the model by Ohlson (1995), Aboody et al. (2002), and study results by Collins et al. (1997), Dechow et al. (1999), Frankel \& Lee (1998), Hand \& Landsman (2005), King \& Langli (1998), Ota (2002), Dang et al. (2018a), Dang et al. (2018b), Ha et al. (2018). To conduct a comprehensive investigation of the impact of accounting information on financial statements on stock prices, we developed the following model:

Priceit $=\beta 0+\beta 1 \mathrm{kAccounting}$ Information it+uit

Appendix 1 presents 52 information indicators that we collected from the financial statements.

\section{Research data}

Research data is the secondary data collected from companies' financial statements listed on the Vietnamese stock market in 2008-2019. The share price (P) is published on March 31 every year.

\section{Analytical method}

When listing variables for linear models, it is typical for studies to consider the P-value. This can be deceptive, as significant factors with a high correlation, but a low P-value can be overlooked. On the other side, irrelevant variables might be incorporated in the model, increasing the model's management complexity. Additionally, an excess problem might occur if the number of observations is smaller than the number of variables in the model. Tibshirani (1996) proposed LASSO as an extension of OLS regression that performs both variable selection and formalization via constraint coefficients. It has the potential to improve the accuracy and interpretability of regression models when compared to standard regression methods (Tibshirani, 1996). The following is the procedure:

To begin, a lambda adjustment parameter () is applied to the model in order to control the intensity of the penalty. With increasing lambda, the many coefficients become zero. When lambda equals 0 , we have OLS regression. When lambda increases, deviation increases, and variance reduces. Second, LASSO regression can improve the model's interpretability. Often, in many linear regressions, certain explanatory factors are unrelated to the dependent variable, resulting in an over- 


\section{GENERAL MANAGEMENT}

equipped and hard model. The coefficients of unimportant variables are lowered to zero using LASSO.

The process of implementing the LASSO method is below:

Step 1: Normalize the data of the independent variables. Only perform the given transformation for the dependent variable to average 0 .

Step 2: Randomly divide the data set into training set and test set at an $80 \%-20 \%$ rate.

Step 3: Since the sample data is panel data, perform model estimation using the two-way estimation technique in the same group to control the effects of time factor and individual factors of each bank. On that basis, using the dimensionality reduction algorithm, the cross-validation procedure to find the best $\lambda$ and implementing the LASSO estimation method with the best $\lambda$ on the training set.

The cross-validation procedure is one of the methods used to find the best estimator for $\lambda$. In the cross-validation procedure, the data set is randomly divided into $\mathrm{K}$ subsets, denoted $\mathrm{C} 1, \ldots, \mathrm{Ck}$. For each value of $\lambda$, the cross-validation procedure is performed as follows: Consider $\mathrm{Ci}$ as the test set, $(\mathrm{K}-1)$ the remaining set as the training set. Applying the LASSO estimation method on this training set to obtain the model, then using the test set $\mathrm{Ci}$ to predict the value of the dependent variable and record the value of MSEi (Mean Squared Error) Repeat with $\mathrm{i}=1,2, \ldots, \mathrm{K}$. Let CVM $\lambda$ be the average of the MSEi: $\mathrm{CVM}_{\lambda}=\frac{\sum_{\mathrm{i}=1}^{\mathrm{K}} \mathrm{MSE}_{\mathrm{i}}}{\mathrm{K}}$

Thus, each $\mathrm{i}$ corresponds to one CVM $\lambda$. When $\mathrm{i}$ is variable over a given set, the best value of $\lambda$ is the one corresponding to the smallest CVM $\lambda$.

Step 4: Calculate the MSE of the models corresponding to the LASSO estimation method on the test set.

Step 5: Repeat 100 times from Step 2 to Step 4 to compare the MSE of the corresponding models with the LASSO estimation method on the test set.

\section{Results and Discussion}

Table 1 describes the average stock prices of listed companies in the period 2008-2019. The lowest prices were in 2008 and the highest peaks in 2017.

\begin{tabular}{|l|l|l|l|}
\hline Year & Number of observations & Average & Median \\
\hline 2008 & 254 & $5,687.40$ & 4,640 \\
\hline 2009 & 357 & $12,073.25$ & 10,000 \\
\hline 2010 & 479 & $8,912.56$ & 7,210 \\
\hline 2011 & 505 & $7,209.52$ & 5,300 \\
\hline 2012 & 523 & $8,139.54$ & 5,430 \\
\hline 2013 & 533 & $11,714.20$ & 8,680 \\
\hline 2014 & 557 & $12,945.57$ & 9,500 \\
\hline 2015 & 601 & $15,433.11$ & 10,700 \\
\hline 2016 & 630 & $19,126.54$ & 12,445 \\
\hline 2017 & 669 & $21,905.99$ & 13,580 \\
\hline 2018 & 688 & $21,031.00$ & 13,450 \\
\hline 2019 & 705 & $16,656.48$ & 11,000 \\
\hline Total / Average & 6,501 & $14,392.91$ & 9,180 \\
\hline
\end{tabular}

Table 1: Descriptive statistics of stock prices in the period 2008-2019 Source: Authors' calculation using Stata 16, 2021

According to the descriptive data for the variables in the study model (Table 1), the stock has a high of 249,700 VND per share and a low of 200 VND per share, with a huge standard deviation of 17,763.20 VND. Due to the large disparity between the average and median stock prices, we first algorithmize the stock price before performing scale regression using the LASSO method.

We separated the research sample into two equal groups,
Training and Testing, and then used the LASSO regression method with the CV, adaptive, and plugin variables. Appendix 2 and Appendix 3 include the final results. The results indicate that among 52 indicators, the effect of accounting information on financial statements on stock prices is determined by 16 variables using the CV option, 13 factors using the adaptive option, and 7 factors using the plugin option.

\begin{tabular}{|l|l|l|l|l|l|}
\hline \multirow{2}{*}{ No. } & \multirow{2}{*}{ Variables } & \multirow{2}{*}{ Code } & \multicolumn{2}{l|}{ Coefficient } \\
\cline { 4 - 6 } & & & cv & adaptive & plugin \\
\hline 1 & Book value per share (BV) & X42 & 0.1932 & 0.2072 & 0.1753 \\
\hline 2 & Company size (Total revenue) & X2 & 0.1923 & 0.2253 & 0.1718 \\
\hline 3 & Return on total assets (ROA) & X37 & 0.1745 & 0.1803 & 0.1147 \\
\hline 4 & Current ratio & X8 & 0.0792 & 0.0932 & 0.0656 \\
\hline 5 & Earnings per share (EPS) & X40 & 0.0749 & 0.0642 & 0.1006 \\
\hline 6 & Gross profit margin & X34 & 0.0732 & 0.0977 & 0.0413 \\
\hline 7 & Company size (Total assets) & X1 & 0.0273 & 0.0126 & 0.0096 \\
\hline 8 & Fixed assets ratio & X33 & -0.0127 & -0.0298 & \\
\hline 9 & Coefficient of periodic interest payment & X17 & 0.0112 & 0.0175 & \\
\hline
\end{tabular}




\section{GENERAL MANAGEMENT}

\begin{tabular}{|l|l|l|l|l|l|}
\hline \multirow{2}{*}{ No. } & \multirow{2}{*}{ Variables } & \multirow{2}{*}{ Code } & \multicolumn{3}{l|}{ Coefficient } \\
\cline { 4 - 6 } & & & cv & adaptive & plugin \\
\hline 10 & Account receivables turnover & X25 & 0.0105 & 0.0113 & \\
\hline 11 & Coefficient of long-term debt solvency & X15 & 0.0075 & 0.0087 & \\
\hline 12 & Revenue growth & X3 & 0.0069 & 0.0043 & \\
\hline 13 & Change in earnings per share (EPS) & X41 & -0.0065 & -0.0073 & \\
\hline 14 & Net trade cycle & X30 & 0.0039 & & \\
\hline 15 & Return on total equity (ROE) & X38 & -0.0007 & & \\
\hline 16 & Financial leverage & X50 & -0.0003 & & \\
\hline
\end{tabular}

Table 2: Summary of variables affecting stock prices

Source: Authors' calculation using Stata 16, 2021

Table 2 lists the accounting information variables that affect stock prices on financial statements. To begin, the book value per share variable has the greatest positive effect on stock price (25.8\%), which is consistent with the findings of Ohlson (1995), Khanagha (2011), Omokhudu \& Ibadin (2015), and Khanna (2014). Second, the size of the company (as measured by total revenue) has the second-largest positive impact on the stock price (25.3 percent). This study's findings are congruent with those of Sharma et al. (2012).

Profitability is the third category of characteristics that has a positive effect on stock prices. This category includes return on total assets (ROA), earnings per share (EPS), and gross profit margin. This study's findings are consistent with those of Collins et al. (1997), Dechow et al. (1999), Frankel \& Lee (1998), Hand \& Landsman (2005), King \& Langli (1998), and Ota et al. (2002).

Finally, the current ratio is favorably correlated with the stock price, indicating that investors prefer enterprises with a large cash and cash equivalents position.

\section{Recommendation and Conclusion}

The findings of this study establish empirical evidence regarding the effect of accounting information contained in financial statements on the stock prices of companies listed on the Vietnamese stock market from 2008 to 2019. We used the LASSO approach to conduct a detailed review of 52 indicators on financial statements in order to identify significant factors influencing the stock price. These characteristics include the book value per share, the company's size, the profitability of the business, and the rapid solvency ratio. Contrary to prevalent opinion that accounting information about businesses is irrelevant to investors in the Vietnamese stock market, this study presents empirical evidence that accounting information variables do have an effect on market stock price movements when they are publicized. Due to the difficulty of establishing the efficient market hypothesis in a developing stock market such as Vietnam, the application of Ohlson's (1995) model in conjunction with Abodyy's (2002) approach to price adjustment is critical for establishing a sound theoretical foundation for quantifying this effect.

Based on the above research results, the authors propose some recommendations as follows:

\section{For listed companies}

On promptly, provide complete accounting information on financial statements. After three months after the fiscal year closes, the relationship between accounting information and stock price is best described (March 31 every year). Additionally, this is the time period during which businesses must publish their year-end financial results. Thus, timely and complete disclosure of financial statements, audit reports, and the Board of Directors' report fosters investor confidence in openness and serves as a good signal for attracting investors.

Ascertain timely and correct disclosure of significant facts about the company, such as its financial condition, business performance, ownership structure, and quality management. Financial markets in general, and the stock market in particular, are complicated environments that demand complete disclosure of information. Additionally, information users require assurances regarding the information's dependability. An appropriate method for disclosing information is necessary for recruiting capital and instilling investor confidence. In comparison, an inadequate and opaque disclosure method can result in ethical infractions that harm the business, its shareholders, and the economy.

\section{For investors}

When investing in securities, it is critical to pay close attention to accounting information because it has the potential to alter the stock price. However, in addition to the information given in the company's financial statements, it is required to refer to book value per share (BV) provided by other sources.

Investors must understand how to conduct financial statement reviews of parent companies and subsidiaries and be wary of accounting gimmicks used by some corporations. Additionally, investors should analyze the timing of the release of the company's financial statements and cast doubt on organizations that aim to publish their financial information late.

\section{For auditing company}

The auditor examines the financial accounts and expresses an opinion on their accuracy, reasonableness, and conformity with accounting and auditing standards and applicable law. The auditor will express exclusion or disapproval of the financial statements data in non-conformities.

Each auditor and accountant must be aware of and adhere to his or her professional and ethical principles in all circumstances. When accountants and auditors are aware of circumstances that jeopardize their ethical behavior, they can take steps to safeguard, remove, or minimize that risk.

\section{References}

[1] Abody, D., Hughes, J., \& Liu, J. (2002). Measuring Value Relevance in a (Possibly) Inefficient Market. Journal of Accounting Research, 40(4), 965-986. doi:10.1111/1475679x.00078

[2] Akbar, S., \& Stark, A. W. (2003). Deflators, Net Shareholder Cash Flows, Dividends, Capital Contributions and Estimated Models of Corporate Valuation. Journal of Business Finance <html_ent Glyph="@amp;" Ascii="\&amp;"/> Accounting, 30(910), 1211-1233. doi:10.1111/j.0306-686x.2003.05514.x 


\section{GENERAL MANAGEMENT}

[3] Alfaraih, M., \& Alanezi, F. (2011). The usefulness of earnings and book value for equity valuation to Kuwait stock exchange participants. The International Business \& Economics Research Journal, 10(1), 73-89.

[4] Ball, R., \& Brown, P. (1968). An empirical evaluation of accounting income numbers. Journal of accounting research, 6(2), 159-178.

[5] Barth, M. E., Beaver, W. H., \& Landsman, W. R. (1998). Relative valuation roles of equity book value and net income as a function of financial health. Journal of Accounting and Economics, 25(1), 1-34. doi:10.1016/s0165-4101(98)00017-2

[6] Chen, C. J., Chen, S., \& Su, X. (2001). Is accounting information value-relevant in the emerging Chinese stock market? Journal of International Accounting, Auditing and Taxation, 10(1), 1-22. doi:https://doi.org/10.1016/S10619518(01)00033-7

[7] Collins, D. W., \& Kothari, S. P. (1989). An analysis of intertemporal and cross-sectional determinants of earnings response coefficients. Journal of Accounting and Economics, 11(2-3), 143-181. doi:10.1016/0165-4101(89)90004-9

[8] Collins, D. W., Maydew, E. L., \& Weiss, I. S. (1997). Changes in the value-relevance of earnings and book values over the past forty years. Journal of Accounting and Economics, 24(1), 39-67. doi:10.1016/s0165-4101(97)00015-3

[9] Dang, N. H., Hoang, T. V. H., \& Dang, T. B. (2018a). Impact of accounting information on financial statements to the stock price of the energy enterprises listed on Vietnam's stock market. International Journal of Energy Economics and Policy, $8(2), 1-6$.

[10] Dang, N. H., Tran, M. D., \& Nguyen, T. L. A. (2018b). Investigation of the impact of financial information on stock prices: The case of Vietnam. Academy of Accounting and Financial Studies Journal, 22(2).

[11] Dechow, P. M., Hutton, A. P., \& Sloan, R. G. (1999). An empirical assessment of the residual income valuation model. Journal of Accounting and Economics, 26(1-3), 1-34. doi:10.1016/s0165-4101(98)00049-4

[12] Dung, N. V. (2010). Value-relevance of financial statement information: A flexible application of modern theories to the Vietnamese stock market. Quarterly Journal of Economics, 84, 488-500.

[13] Frankel, R., \& Lee, C. M. (1998). Accounting valuation, market expectation, and cross-sectional stock returns. Journal of accounting and economics, 25(3), 283-319.

[14] Green, J. P., Stark, A. W., \& Thomas, H. M. (1996). UK evidence on the market valuation of research and development expenditures. Journal of Business Finance \& Accounting, 23(2), 191-216.

[15] Ha, H. T. V., Hung, D. N., \& Dung, T. M. (2018). Impact of Accounting Data on Stock Prices: The Case of Vietnam. International Journal of Accounting and Financial Reporting, 8(1), 140-154.

[16] Hand, J. R., \& Landsman, W. R. (2005). The pricing of dividends in equity valuation. Journal of Business Finance \& Accounting, 32(3-4), 435-469.
[17] Iqbal, A., Ahmed, F., \& Shafi, A. R. (2014). The effect of dividend bubble on share price: Evidence from KSE-30 index. Research Journal of Finance and Accounting, 5(13), 83-87.

[18] Jensen, M. C., \& Meckling, W. H. (1976). Theory of the firm: Managerial behavior, agency costs and ownership structure. Journal of financial economics, 3(4), 305-360.

[19] Kaundal, R., \& Sharma, S. (2010). Stock Market Integration: Examining Linkages between India and Select Asian Markets. Foreign Trade Review, 45(3), 3-18.

[20] Khanagha, J. B. (2011). Value relevance of accounting information in the United Arab Emirates. International Journal of Economics and Financial Issues, 1(2), 33.

[21] Khanna, M. (2014). Value Relevance of Accounting Information: An Empirical Study of Selected Indian Firms International Journal of Scientific and Research Publications, 4(10), 1-6.

[22] King, R. D., \& Langli, J. C. (1998). Accounting diversity and firm valuation. The International Journal of Accounting, 33(5), 529567.

[23] Lev, B., \& Ohlson, J. A. (1982). Market-based empirical research in accounting: A review, interpretation, and extension. Journal of accounting research, 20(1), 249-322.

[24] Lo, K., \& Lys, T. (2000). The Ohlson model: contribution to valuation theory, limitations, and empirical applications. Journal of Accounting, Auditing \& Finance, 15(3), 337-367.

[25] Malkiel, B. G., \& Fama, E. F. (1970). Efficient capital markets: A review of theory and empirical work. The journal of finance, 25(2), 383-417.

[26] Ohlson, J. A. (1995). Earnings, book values, and dividends in equity valuation. Contemporary Accounting Research, 11(2), 661-687.

[27] Omokhudu, O. O., \& Ibadin, P. O. (2015). The value relevance of accounting information: Evidence from Nigeria. Accounting and Finance Research, 4(3), 20-30.

[28] Ota, K. (2002). A test of the Ohlson (1995) model: Empirical evidence from Japan. The International Journal of Accounting, 37(2), 157-182.

[29] Rees, W. P. (1997). The impact of dividends, debt and investment on valuation models. Journal of Business Finance \& Accounting, 24(7-8), 1111-1140. DOI: 10.1111/14685957.00154

[30] Shamki, D. (2012). Impact of non accounting information on the value relevance of accounting information: The case of Jordan. International Journal of Business and Social Research, 2(1), 9-24

[31] Sharma, A. K., Kumar, S., \& Singh, R. (2012). Value relevance of financial reporting and its impact on stock prices: Evidence from India. South Asian Journal of Management, 19(2), 60.

[32] Stark, A. W., \& Thomas, H. M. (1998). On the empirical relationship between market value and residual income in the UK. Management Accounting Research, 9(4), 445-460. doi:https://doi.org/10.1006/mare.1998.0088

[33] Walker, M. (1997). Clean surplus accounting models and market-based accounting research: a review. Accounting and business research, 27(4), 341-355.

\begin{tabular}{|l|l|l|}
\hline Code & Variables & Measurement \\
\hline $\mathbf{P}$ & Stock price & Stock price on date 31/03/N+1 \\
\hline X1 & Company size (Total assets) & Log (Total assets) \\
\hline X2 & Company size (Total revenue) & Log (Total revenue) \\
\hline X3 & Revenue growth & (Revenuet - Revenuet-1) / Revenuet \\
\hline X4 & Assets growth & (Total assetst - Total assetst-1) / Total assetst \\
\hline X5 & Assets to debts ratio & Total assets / Total debts \\
\hline X6 & $\begin{array}{l}\text { Coefficient of short-term debt } \\
\text { solvency }\end{array}$ & Total current assets / Total short-term liabilities \\
\hline X7 & Current ratio & (Current assets - Inventory) / Total short-term liabilities \\
\hline X8 & Quick solvency ratio & Cash and cash equivalents / Total short-term liabilities \\
\hline
\end{tabular}




\section{GENERAL MANAGEMENT}

\begin{tabular}{|c|c|c|}
\hline Code & Variables & Measurement \\
\hline X9 & $\begin{array}{l}\text { Cash flows / Total short-term } \\
\text { liabilities ratio }\end{array}$ & $\begin{array}{l}\text { Net cash flow from operating activities / Average short- } \\
\text { term liabilities }\end{array}$ \\
\hline $\mathrm{X} 10$ & Cash flow / Debt-to-maturity ratio & Net cash flow from operating activities / Debt-to-maturity \\
\hline $\mathrm{X} 11$ & Debt ratio & Total debt / Total liabilities \\
\hline $\mathrm{X} 12$ & Financing factor & Total equity / Total liabilities \\
\hline $\mathrm{X} 13$ & Liabilities / Equity ratio & Total liabilities / Total equity \\
\hline $\mathrm{X} 14$ & Liabilities / Collateral ratio & $\begin{array}{l}\text { Total liabilities / (Total assets - Intangible assets + Land } \\
\text { use rights) }\end{array}$ \\
\hline $\mathrm{X} 15$ & $\begin{array}{l}\begin{array}{l}\text { Coefficient of long-term debt } \\
\text { solvency }\end{array} \\
\end{array}$ & Long-term assets / Long-term debt \\
\hline $\mathrm{X} 16$ & $\begin{array}{l}\text { Coefficient of loan interest } \\
\text { solvency }\end{array}$ & $\begin{array}{l}\text { Profit before corporate income tax and interest } \\
\text { expenses / Interest expenses }\end{array}$ \\
\hline $\mathrm{X} 17$ & $\begin{array}{l}\text { Coefficient of periodic interest } \\
\text { payment }\end{array}$ & Average cash / Average interest payable \\
\hline $\mathrm{X} 18$ & Capital mobilization & (Equity + Long-term debt) / Fixed assets \\
\hline $\mathrm{X} 19$ & Retained earnings on equity & Retained earnings / Total equity \\
\hline $\mathrm{X} 20$ & Assets turnover & Net revenue / Total assets \\
\hline $\mathrm{X} 21$ & Current assets turnover & Net revenue / Current assets \\
\hline $\mathrm{X} 22$ & Inventory turnover & Net revenue / Average inventory \\
\hline $\mathrm{X} 23$ & Inventory turnover & Cost of goods sold / Average inventory \\
\hline $\mathrm{X} 24$ & Inventory turnover (days) & Average inventory value $\times 365$ / Cost of goods sold \\
\hline $\mathrm{X} 25$ & Account receivables turnover & Net revenue / Account receivables \\
\hline $\mathrm{X} 26$ & $\begin{array}{lll}\begin{array}{l}\text { Account } \\
\text { (days) }\end{array} & \text { receivables turnover } \\
\end{array}$ & $\begin{array}{l}\text { (Accounts receivable from customers } \times 365 \text { ) / Net } \\
\text { revenue }\end{array}$ \\
\hline $\mathrm{X} 27$ & Payable turnover & Costs of goods sold / Account payables \\
\hline $\mathrm{X} 28$ & Payables turnover (days) & (Account payables $\times 365$ ) / Cost of goods sold \\
\hline X29 & Cash conversion cycle & $\begin{array}{l}\text { Average receivables } \times 365 \text { / Total revenue + Average } \\
\text { inventory } \times 365 / \text { Cost of goods sold - Average payables } \\
\times 365 \text { / Cost of goods sold }\end{array}$ \\
\hline $\mathrm{X} 30$ & Net trade cycle & $\begin{array}{l}\text { (Average receivables + Average inventory - Average } \\
\text { payables) } \times 365 / \text { Total revenue }\end{array}$ \\
\hline $\mathrm{X} 31$ & Long-term asset cycles & Net revenue / Long term assets \\
\hline $\mathrm{X} 32$ & Production capacity of fixed assets & Net revenue / Fixed assets \\
\hline X33 & Fixed assets ratio & Net book value of fixed assets / Total assets \\
\hline X34 & Gross profit margin & (Net revenue - Cost of goods sold) / Net revenue \\
\hline X35 & $\begin{array}{l}\text { Profit before tax and interest } \\
\text { expense }\end{array}$ & (Profit before tax + Interest expense) $/$ Net revenue \\
\hline X36 & $\begin{array}{l}\text { Profit before tax, interest expense } \\
\text { and depreciation }\end{array}$ & $\begin{array}{l}\text { (Profit before tax }+ \text { Interest expense }+ \text { Depreciation } \\
\text { expense) } / \text { Net revenue }\end{array}$ \\
\hline X37 & Return on total assets (ROA) & Profit after tax / Total assets \\
\hline X38 & Return on total equity (ROE) & Profit after tax / Total equity \\
\hline X39 & $\begin{array}{l}\text { Profit after tax to Net revenue } \\
\text { (ROS) }\end{array}$ & Profit after tax / Net revenue \\
\hline $\mathrm{X} 40$ & Earnings per share (EPS) & $\begin{array}{l}\text { (Profit after tax - Dividends of preferred shares) / } \\
\text { Average number of common shares outstanding }\end{array}$ \\
\hline $\mathrm{X} 41$ & $\begin{array}{l}\text { Change in earnings per share } \\
\text { (EPS) }\end{array}$ & $\begin{array}{l}\text { (Earnings per share (EPS)t - Earnings per share (EPS)t- } \\
\text { 1) / Earnings per share (EPS)t-1 }\end{array}$ \\
\hline $\mathrm{X} 42$ & Book value per share (BV) & $\begin{array}{l}\text { Book value of equity / Number of common shares in } \\
\text { circulation }\end{array}$ \\
\hline $\mathrm{X} 43$ & Cash ratio & Cash / Total assets \\
\hline $\mathrm{X} 44$ & Short-term debt ratio & Short-term debt / Total assets \\
\hline $\mathrm{X} 45$ & Long-term debt ratio & Long-term debt / Total assets \\
\hline $\mathrm{X} 46$ & Financial leverage & Total debt / Total assets \\
\hline $\mathrm{X} 47$ & Cash ratio (squared) & Squared (Cash / Total assets) \\
\hline $\mathrm{X} 48$ & Short-term debt ratio (squared) & Squared (Short-term debt / Total assets) \\
\hline
\end{tabular}




\section{GENERAL MANAGEMENT}

\begin{tabular}{|l|l|l|}
\hline Code & Variables & Measurement \\
\hline X49 & Long-term debt ratio (squared) & Squared (Long-term debt / Total assets) \\
\hline X50 & Financial leverage (squared) & Squared (Total debt / Total assets) \\
\hline X51 & Cash conversion cycle (squared) & $\begin{array}{l}\text { Squared (Average receivables } \times 365 / \text { Total revenue + } \\
\text { Average inventory } \times 365 / \text { Cost of goods sold }- \text { Average } \\
\text { payables } \times 365 / \text { Cost of goods sold) }\end{array}$ \\
\hline X52 & Net trade cycle (squared) & $\begin{array}{l}\text { Squared ((Average receivables + Average inventory - } \\
\text { Average payables) } \text { x 365 / Total revenue) }\end{array}$ \\
\hline
\end{tabular}

Appendix 1: Variables used in the research model Source: Authors' compilation, 2021

Lasso linear model
No. of obs
2,080
No. of covariates $=$
51
No. of $\mathrm{CV}$ folds $=10$

Selection: Cross-validation

\begin{tabular}{r|rrrrr}
\hline & lambda & $\begin{array}{r}\text { No. of } \\
\text { nonzero } \\
\text { coef. }\end{array}$ & $\begin{array}{r}\text { Out-of- } \\
\text { sample } \\
\text { R-squared }\end{array}$ & $\begin{array}{r}\text { CV mean } \\
\text { prediction } \\
\text { error }\end{array}$ \\
\hline 1 & first lambda & .4429704 & 0 & 0.0036 & .7094107 \\
32 & lambda before & .0247656 & 15 & 0.4156 & .4160931 \\
33 & selected lambda & .0225655 & 16 & 0.4157 & .415999 \\
34 & lambda after & .0205609 & 16 & 0.4153 & .4162641 \\
37 & last lambda & .0155535 & 18 & 0.4116 & .4188886 \\
\hline
\end{tabular}

* lambda selected by cross-validation.

Appendix 2: Results of lambda and variables selection according to LASSO method

Option cv

Source: Authors' calculation using Stata 16, 2021

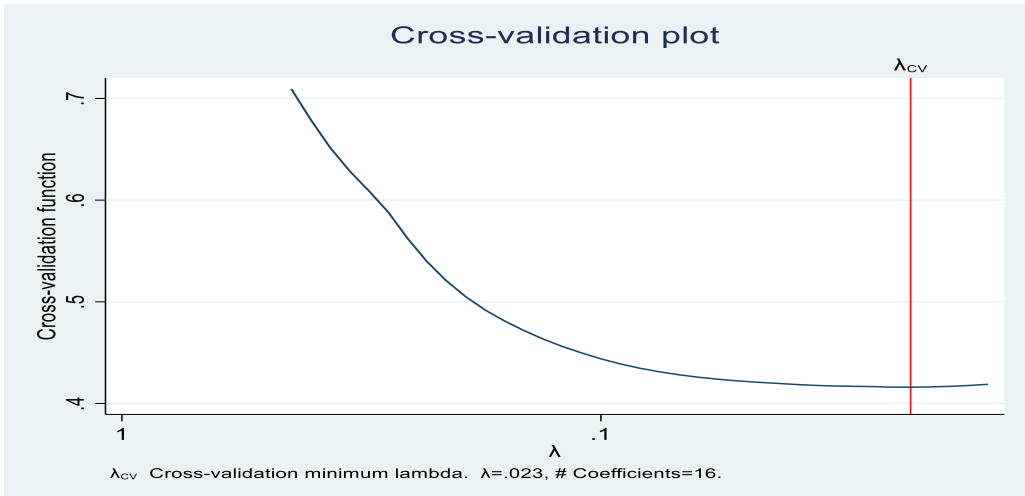

Source: Authors' calculation using Stata 16, 2021

\section{Option adaptive}

\begin{tabular}{|c|c|c|c|c|c|}
\hline \multicolumn{3}{|c|}{ Lasso linear model } & $\begin{array}{l}\text { No. of } \\
\text { No. of } \\
\text { No. of }\end{array}$ & $\begin{array}{l}\text { bs } \\
\text { ovariates } \\
\text { asso steps }\end{array}$ & $\begin{array}{r}2,080 \\
51 \\
2\end{array}$ \\
\hline \multicolumn{6}{|c|}{ Final adaptive step results } \\
\hline ID & Description & lambda & $\begin{array}{c}\text { No. of } \\
\text { nonzero } \\
\text { coef. }\end{array}$ & $\begin{array}{r}\text { Out-of- } \\
\text { sample } \\
\text { R-squared }\end{array}$ & $\begin{array}{r}\text { CV mean } \\
\text { prediction } \\
\text { error }\end{array}$ \\
\hline 38 & first lambda & 26.98218 & 0 & 0.0015 & .7108721 \\
\hline 103 & lambda before & .0637991 & 13 & 0.4207 & .4124281 \\
\hline * 104 & selected lambda & .0581313 & 13 & 0.4208 & .4123537 \\
\hline 105 & lambda after & .0529671 & 13 & 0.4208 & .412389 \\
\hline 137 & last lambda & .0026982 & 15 & 0.3983 & .428375 \\
\hline
\end{tabular}

* lambda selected by cross-validation in final adaptive step.

Source: Authors' calculation using Stata 16, 2021 


\section{GENERAL MANAGEMENT}

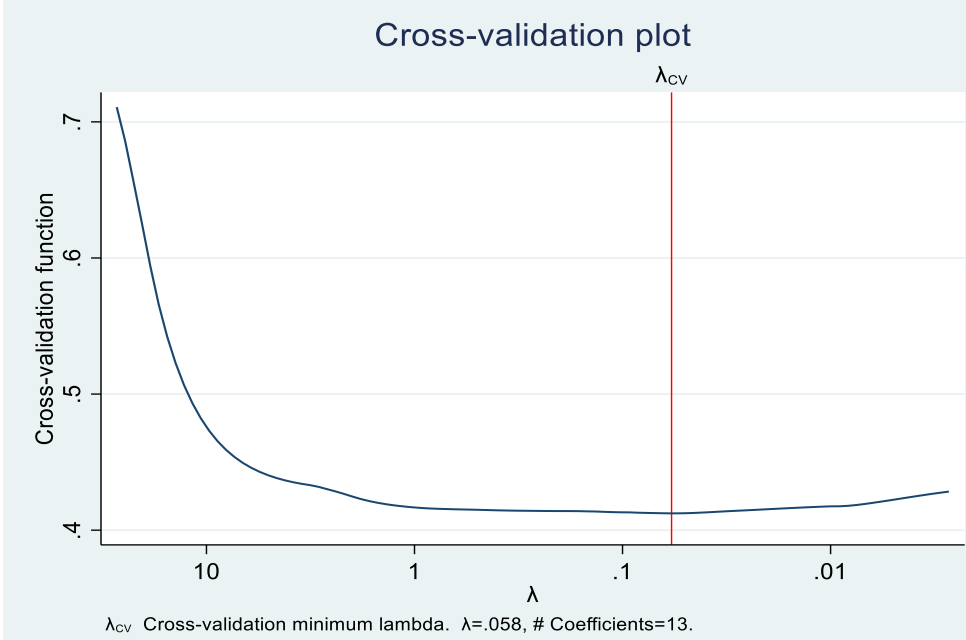

Source: Authors' calculation using Stata 16, 2021

\section{Option a plugin}

Lasso linear model

Selection: Plugin heteroskedastic

\begin{tabular}{|c|c|c|c|c|c|}
\hline ID & Description & lambda & $\begin{array}{c}\text { No. of } \\
\text { nonzero } \\
\text { coef. }\end{array}$ & $\begin{array}{l}\text { In-sample } \\
\text { R-squared }\end{array}$ & BIC \\
\hline$* 1$ & selected lambda & .0881683 & 7 & 0.4059 & 4174.226 \\
\hline
\end{tabular}

* lambda selected by plugin formula assuming heteroskedastic.

Source: Authors' calculation using Stata 16, 2021

Penalized coefficients

\begin{tabular}{|c|c|c|c|c|}
\hline Name & sample & MSE & R-squared & Obs \\
\hline \multicolumn{5}{|l|}{$c V$} \\
\hline & Training & .4215072 & 0.4204 & 2,271 \\
\hline & Testing & .4587657 & 0.3284 & 2,313 \\
\hline \multicolumn{5}{|c|}{ adaptive } \\
\hline & Training & .4238869 & 0.4172 & 2,271 \\
\hline & Testing & .4637182 & 0.3212 & 2,313 \\
\hline \multicolumn{5}{|c|}{ plugin } \\
\hline & Training & .4900035 & 0.3443 & 3,075 \\
\hline & Testing & .4791921 & 0.3249 & 3,102 \\
\hline
\end{tabular}

Appendix 3: Comparison among options according to the LASSO method Source: Authors' calculation using Stata 16, 2021 